\title{
Utilizing Peptide Ligand GPCRs to Image and Treat Pancreatic Cancer
}

\author{
Gail L. Matters ${ }^{1, *}$ and John F. Harms ${ }^{2}$ \\ 1 Department of Biochemistry and Molecular Biology, The Pennsylvania State University College of Medicine, \\ Hershey, PA 17033, USA \\ 2 Department of Biological Sciences, Messiah College, Mechanicsburg, PA 17055, USA; jharms@messiah.edu \\ * Correspondence: gmatters@pennstatehealth.psu.edu; Tel.: +1-717-531-4098
}

Received: 15 May 2018; Accepted: 28 May 2018; Published: 2 June 2018

\begin{abstract}
It is estimated that early detection of pancreatic ductal adenocarcinoma (PDAC) could increase long-term patient survival by as much as 30\% to $40 \%$ (Seufferlein, T. et al., Nat. Rev. Gastroenterol. Hepatol. 2016, 13, 74-75). There is an unmet need for reagents that can reliably identify early cancerous or precancerous lesions through various imaging modalities or could be employed to deliver anticancer treatments specifically to tumor cells. However, to date, many PDAC tumor-targeting strategies lack selectivity and are unable to discriminate between tumor and nontumor cells, causing off-target effects or unclear diagnoses. Although a variety of approaches have been taken to identify tumor-targeting reagents that can effectively direct therapeutics or imaging agents to cancer cells (Liu, D. et al., J. Controlled Release 2015, 219, 632-643), translating these reagents into clinical practice has been limited, and it remains an area open to new methodologies and reagents (O'Connor, J.P. et al., Nat. Rev. Clin. Oncol. 2017, 14, 169-186). G protein-coupled receptors (GPCRs), which are key target proteins for drug discovery and comprise a large proportion of currently marketed therapeutics, hold significant promise for tumor imaging and targeted treatment, particularly for pancreatic cancer.
\end{abstract}

Keywords: G protein-coupled receptors; cholecystokinin; gastrin; gastrin-releasing peptide; bombesin; neurokinin; neurotensin; somatostatin

\section{Introduction}

The utility of reagents to enhance tumor imaging or direct treatment often relies on tumor-targeting ligands that bind to proteins that are overexpressed on the surface of malignant cells [1-3]. Tumor-directed targeting can make use of antibodies, peptides, small molecules, or other moieties, and can result in a higher cargo concentration either within or on the surface of tumor cells than would be attained without targeting [4]. In pancreatic ductal adenocarcinoma (PDAC), development of targeted therapies has focused on receptor tyrosine kinases (RTKs) or their downstream pathways, with limited efficacy [5]. G protein-coupled receptors (GPCRs) represent an opportunity to develop new targeted therapeutics and imaging agents for pancreatic cancer [6] (Figure 1). 


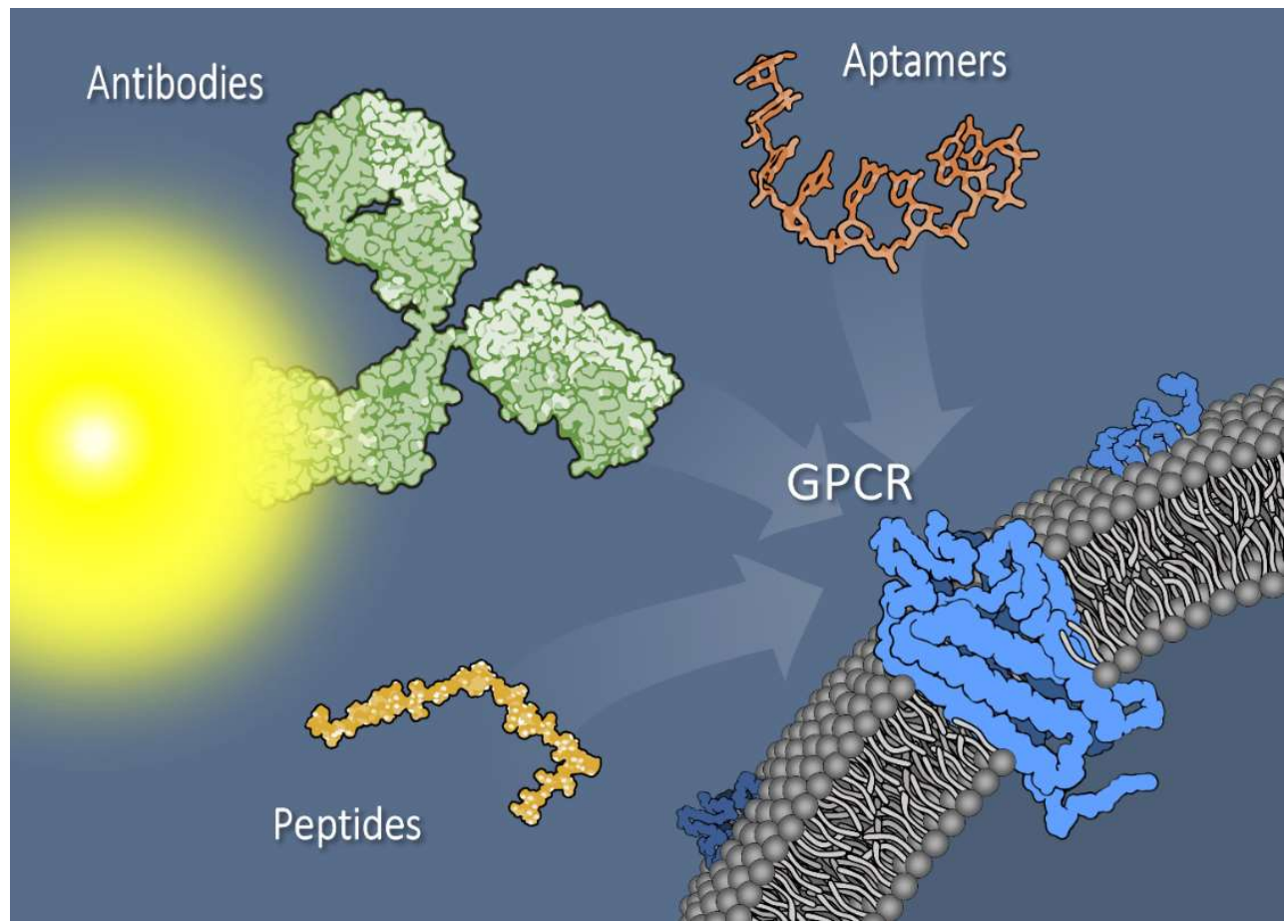

Figure 1. Pancreatic tumor cell surface membrane with G protein-coupled receptors (GPCRs) can be targeted with a variety of reagents, including antibodies (depicted as dye-conjugated) or antibody fragments, aptamers, or small peptides. Additionally, novel bi- or multivalent combinations of targeting agents exhibit promise as tools for imaging and treatment. Targeting agents are not drawn to scale.

\section{G Protein-Coupled Receptors}

GPCRs are plasma membrane proteins composed of seven transmembrane-spanning $\alpha$-helices linked by three intracellular and three extracellular loop regions, an extracellular amino-terminal domain, and an intracellular carboxyl-terminal domain. Classical GPCR signaling is initiated by a ligand interacting with extracellular receptor loop/transmembrane domain residues, which form a ligand-binding pocket. This interaction triggers a conformational change in the receptor that initiates binding and activation of intracellular heterotrimeric $G$ proteins. The exchange of guanosine diphosphate (GDP) for guanosine triphosphate (GTP) on the G alpha subunit dissociates $G$ alpha from the $G$ beta/gamma subunits and activates numerous downstream effector pathways $[7,8]$. Receptor activation is followed by desensitization and internalization. Once activated, GPCRs are phosphorylated by G protein kinases (GPKs), and cytosolic $\beta$-arrestins can then bind to the GPCRs, competing with the GPCR-G protein interaction and downregulating $\mathrm{G}$ protein-mediated signaling. The GPCR / $\beta$-arrestin complex can follow one of the endocytic pathways [9], in which GPCRs can either be recycled back to the plasma membrane or sent to the lysosomes for degradation [10].

GPCRs play an important role in cancer progression, and these proteins have been utilized as therapeutic and imaging targets. Since many chemotherapeutic agents are only active intracellularly, transmembrane transport of targeted cargos is a key issue. Unlike single transmembrane spanning proteins, which are often cleaved by proteases such as matrix metalloproteases (MMPs) to release their ectodomains [11,12], ligand-induced GPCR internalization improves intracellular bioavailability of the cargo. GPCR recycling also provides cell membrane-associated targets for additional rounds of internalization. Increased expression and activity of GPCRs is evident at all stages of PDAC tumor development, and GPCRs contribute to tumor cell proliferation, tumor progression through stimulation of angiogenic and metastatic cascades, and the creation of a proinflammatory tumor microenvironment and evasion of immune cell recognition [13]. 
Recent evidence suggests that mutations in GPCRs and their associated G proteins are common in tumors-approximately $20 \%$ of all cancers contain mutated GPCRs or G alpha subunits [14]. For example, defects that impact GPCR trafficking can contribute to receptor retention at the cell surface and altered downstream signaling. Activating mutations in GPCR-associated proteins, particularly GNAS, which encodes the Gs-alpha subunit, can be present in up to $12 \%$ of pancreatic tumors $[10,14]$. Reduced GTPase activity leads to constitutive signaling that can drive tumor progression. In addition, crosstalk between GPCR and RTK signaling pathways can stimulate receptor transactivation and has been linked to oncogenic Kras activation in early-stage PDAC [15,16].

GPCRs mediate a broad range of autocrine and paracrine responses in cancer cells. They bind to a diverse group of ligands, including small peptides (e.g., gastrointestinal hormones), lipids (e.g., sphingosine-1-phosphate, prostaglandins), and proteins (e.g., chemokines) [8]. The density of GPCRs on the cell surface is typically $10^{3}-10^{4}$ receptors/cell, which should be adequate to ensure ample uptake of the targeted drug cargo or to bind sufficient imaging reagents to achieve quality images $[17,18]$. Herein, we focus on the peptide hormone-ligand subfamily of GPCRs and their use in developing reagents to identify and treat pancreatic cancer.

\section{CCKRs}

The peptides gastrin and cholecystokinin (CCK) activate two structurally related G protein-coupled receptors, the CCK1 receptor (CCK1R) and CCK2 receptor (CCK2R), which are expressed by many PDAC tumors [19]. Although highly homologous, with 50\% overall identity, these receptors differ in their ligand-binding specificities and inhibitor profiles [20]. CCK1R binds with high affinity to CCK-8 amide with a sulfated tyrosine. CCK2R binds gastrin and CCK with similar affinity and does not discriminate between sulfated and nonsulfated CCK, as binding is directed by the final four amino acids of these peptides (Trp-Met-Asp-Phe- $\mathrm{NH}_{2}$, although leucine or norleucine can be interchanged for methionine to improve stability without altering binding affinity) [21]. Functionally, CCK2R expressed on pancreatic tumors plays a role in tumor cell proliferation and angiogenesis [22].

Beginning in the late 1990s, many groups explored the use of CCK1R and CCK2R for tumor imaging and treatment. While anti-CCK2R antibodies have been developed [23,24], most targeting reagents have been peptide analogs of either CCK or gastrin. With a radionuclide chelator attached to the N-terminus of CCK or gastrin peptide analogs, a variety of reagents have been created for tumor imaging and radiotherapy, including CCK-8, gastrin 10, mini-gastrin, gastrin dimers, and cyclic gastrin analogs [25-31]. Although tumor uptake relative to other tissues was good, the ability of the peptide-targeted constructs to deliver cargo to tumors was limited by high proteolytic turnover in serum, often with less than $10 \%$ of the reagent remaining in circulation 10 minutes post-injection [32]. One approach to extending the half-life of gastrin- or CCK-based reagents has been to inhibit the activity of the protease responsible for gastrin/CCK degradation, neutral endopeptidase (NEP). Co-injection of the NEP inhibitor phosphoramidon with gastrin analogs increased their half-life in circulation and improved tumor uptake [33-35]. Finally, nanoparticles can be bioconjugated with gastrin peptide to improve tumor-specific uptake. Attaching gastrin 10 to fluorescent dye-loaded calcium phosphosilicate nanoparticles enhanced particle uptake by orthotopic pancreatic tumors in a murine model [36].

\section{GRP/Bombesin Receptors}

This family of peptide receptors contains gastrin-releasing peptide receptor (GRPR), neuromedin $B$ receptor (NMBR), and bombesin receptor subtype 3 (BRS3), which are overexpressed by a number of cancers, including PDAC [37]. PDAC cells have previously been targeted with a GRPR ligand radiolabeled for positron emission tomography (PET) imaging, or conjugated with $\mathrm{Gd}^{3+}$ for magnetic resonance imaging (MRI) [38,39]. Human gastrin releasing peptide (GRP) as well as mammalian bombesin (BN), which differ by only 1 out of 10 amino acids, have been utilized for GRP- or BN-drug conjugates with paclitaxel or docetaxel. Compared to free drug, the peptide-drug conjugates resulted 
in enhanced cytotoxicity in vitro [40-42]. However, the efficacy of these compounds against pancreatic tumors in vivo remains unclear [43].

\section{Neurokinin Receptors}

The neurokinin-1 receptor (NK1R) and its peptide ligand, substance P (SP), regulate many tumor cell processes, including proliferation, angiogenesis, migration, invasion, and metastasis [44]. NK1R is upregulated in human pancreatic tumors, especially in advanced tumors with poor prognosis, and has recently been implicated in perineural invasion of PDAC tumors [45]. In mice, a subpopulation of PanIN epithelial cells express NK1R. Evidence suggests that these are acinar cell-derived neoplastic PanIN epithelial cells, opening the potential for using NK1R-targeted imaging for detection of early lesions [46]. Tumor imaging using an NK1R-targeted fluorescent dye has been used during surgery to facilitate identification and resection of NK1R-positive lesions [47,48]. In PET imaging, ${ }^{64} \mathrm{Cu}-\mathrm{NK} 1 \mathrm{R}-\mathrm{NOTA}$ is a promising reagent for identifying NK1R-expressing tumors [49], and NK1R-targeted cytotoxic drugs are also under development [50].

\section{Neurotensin Receptors}

Neurotensin receptor (NTS1) has been identified on several PDAC cells lines, in human PDAC tissues, and in late-stage PanINs and PDAC liver metastases, with lower expression in chronic pancreatitis [51,52]. NTS1 binding of the ligand neurotensin (NT) activates mitogenic signaling, while a selective NTS1 antagonist, SR 48692, reduces PDAC cell proliferation [53,54]. Because NT interacts with the NTS1 receptor with high affinity and only the six C-terminal amino acids of NT are required for receptor binding, bioconjugation of NT peptide to a variety of reagents holds potential for improving their delivery to NTS1-expressing tumors [17]. Biodistribution studies using NT-targeted probes in PDAC tumor-bearing mice showed high tumor-specific uptake of ${ }^{68}$ Ga-labeled NT peptides in vivo [55]. In addition to NT peptides, NTS1 small-molecule antagonists labeled with ${ }^{18} \mathrm{~F}$ and ${ }^{177} \mathrm{Lu}$ also demonstrated tumor cell internalization and retention in vivo with low kidney and liver uptake [56,57]. Liposomes functionalized with a branched neurotensin peptide, NT4, and loaded with doxorubicin have been assessed for antitumor cell efficacy in vitro [58].

Interestingly, recent evidence shows that there is crosstalk between the insulin/IGF-1 receptor and NT/NTS1 signaling pathways, which leads to activation of the oncogenic YAP/TAZ pathway. Stimulation of PDAC cells with both insulin and neurotensin results in nuclear localization of YAP, decreased YAP phosphorylation, and increased expression of YAP/TEAD-regulated genes, while treatment with either insulin or neurotensin alone only modestly induced the expression of these genes [59]. This suggests that either antagonism of NTS1 or blockade of downstream signaling pathways connecting to YAP could a be promising therapeutic target for PDAC [60].

\section{Somatostatin Receptors}

Somatostatin receptor (SSTR) subtypes SSTR2, SSTR3, and SSTR5 are present in human PDAC tumors based on mRNA expression [61,62]. The short half-life of somatostatin (SST) prompted the development of several peptide analogs for therapeutic and imaging purposes, the most clinically relevant of which is octreotide (OCT). This eight-amino-acid peptide binds to SSTR2 with high affinity and triggers receptor endocytosis $[18,63,64]$. OCT-drug conjugates, created by direct coupling of camptothecin or paclitaxel to the N-terminus of the peptide, were cytotoxic to cancer cell lines that overexpressed SSTR2 [65] and induced regression of subcutaneous CFPAC-1 tumors in athymic mice [66]. More recently, a reagent that combined MRI/optical imaging capability and a synthetic peptide (PTR86) with high affinity for somatostatin receptors showed efficient imaging and targeting of pancreatic tumors [67]. An SST analog dual-labeled with a radionuclide and fluorescent dye has recently been evaluated in a preclinical colon cancer model system [68].

Interestingly, a PDAC-specific interaction between two GPCRs, the mu opioid receptor (MOR) and SSTR2, has recently been identified [69]. The presence of this GPCR heterodimer correlated with 
increased oncogenic signaling and tumor progression and antagonists to either receptor triggered heterodimer internalization. This suggests that the MOR-SSTR2 heterodimer may represent a unique PDAC-specific target. Investigation of other novel GPCR heterodimers in PDAC may uncover new opportunities for therapeutic targeting with higher tumor cell specificity.

\section{Dual-Targeted Agents}

A challenge for the development of tumor-targeted drug delivery or imaging is the level at which the target protein is expressed. It is well documented that PDAC tumors and metastatic lesions are heterogeneous with regard to their expression of GPCRs and other cell-surface receptors [70]. Dual-targeted reagents are capable of targeting different GPCRs simultaneously, or a GPCR and another extracellular protein. These reagents can achieve better specificity than targeting the proteins individually. Dual-targeting agents also can provide better sensitivity through a greater number of potential tumor cell binding sites, thus enabling clearer visualization of cancerous lesions or improved drug delivery [71].

Simultaneous targeting of two independent GPCRs was achieved using a peptide that combined ligands for the CCK2 receptor and the melanocortin 1 receptor (also known as MC1R) [72]. This bivalent reagent joins seven amino acids from melanocortin to the CCK-4 tetrapeptide via a synthetic fluorescently tagged linker. In vitro, the hybrid ligand was able to bind both cell-surface receptors, demonstrating a 12-fold higher specificity for cells expressing both receptors. The ability of the bivalent ligand to improve the imaging of tumors in vivo was confirmed using tumor cell lines engineered to express either the MSH receptor, CCK2 receptor, or both.

Dual targeting can also exploit a target protein on a nonmalignant cell type within the tumor microenvironment (TME) in addition to a tumor-cell GPCR. Demonstrating this strategy, bombesin was fused to an RGD peptide motif, thereby targeting both a GPCR and integrin $\alpha \mathrm{v} \beta 3$ on tumor endothelial cells [73]. The resulting ${ }^{68} \mathrm{Ga}$-labeled heterodimeric peptide has been successfully employed in PET imaging. A second example, while not targeting a GPCR, demonstrates the utility of bivalent targeting. Pancreatic tumor xenografts were imaged using a heterodimer of antibody fragments targeting CD105 on the tumor vasculature and tissue factor (TF) on tumor cells [74,75]. Further explorations of multivalent combinations of a GPCR-targeted ligand with other TME targets would constitute novel advancements.

\section{Nonpeptide Targeting to GPCRs: Aptamers}

RNA and DNA aptamers are single-stranded, structured oligonucleotides that have promise for both targeted tumor imaging and drug delivery while avoiding some of the common disadvantages of peptide and antibody targeting [76]. Targeting with antibodies can be associated with a risk of inappropriate immune response, while peptides are typically susceptible to proteolytic degradation in the systemic circulation, making them unsuitable for many in vivo applications. Small molecules such as antagonists, while having a well-defined chemical structure and good stability, can have low target selectivity or rapid clearance in vivo [3]. Aptamers have a reproducible structure and can be easily modified to resist nucleases, can be synthesized at a lower cost, are stable to changes in temperature and $\mathrm{pH}$, and can refold spontaneously once conditions normalize. They have fewer nonspecific interactions in the systemic circulation, are less immunogenic, and display high binding affinity to targets with dissociation constant $(\mathrm{Kd})$ values in the nanomolar range. Due to their low molecular weight (25-70 nucleotides is equivalent to 8-20 kDa), aptamers can also penetrate tumor tissues more efficiently than antibodies or Fab fragments [77,78].

Aptamers can be attached to a variety of payloads, including small interfering RNAs (siRNAs), cytotoxic drugs, or nanoparticles, which improves the selective delivery and efficacy of the cargo [79-82]. Tumor-targeting aptamers have been selected for cell-adhesion molecules such as EpCAM, tyrosine kinase receptors, mucins, and other cell-surface proteins [83]. For example, EGFR-targeted aptamers conjugated 
to gold nanospheres have been successfully used to image head and neck tumors [84]. Aptamer-based imaging agents and aptamer-targeted therapeutics are now moving into clinical trials [85].

Our research team has identified and characterized aptamers against the GPCR CCK2R. Using a SELEX-based library selection protocol, we selected aptamers that bound to both a synthetic peptide contained within the extracellular N-terminal domain of the CCK2R and PDAC cells expressing CCK2R in its native conformation. Negative selection with non-CCK2R-expressing cells ruled out nonspecific interactors. Overall, we identified a pool of $>100$ high-affinity DNA aptamers that specifically recognized the extracellular $N$ terminus of the human CCK2R [86]. Quantitatively, we have shown that one of the selected CCK2R aptamers (AP1153) has a 300-fold higher affinity for CCK2R than its native peptide ligand, gastrin. As evidence for its utility as a pancreatic tumor targeting agent, we demonstrated that AP1153 was internalized by PDAC cells in a receptor-mediated fashion, and that bioconjugation of AP1153 to the surface of fluorescent nanoparticles enhanced whole-animal optical detection of PDAC tumors in vivo. Others have identified aptamers that bind to the GPCR NTS1, although their further development for diagnostic or therapeutic use has not yet been shown [87].

Finally, aptamers can have direct therapeutic benefit as antitumor reagents. A variety of RNA aptamers that bind to $\beta 2$-adrenoceptor ( $\beta 2 A R$ ), a non-peptide-liganded GPCR, have been shown to stabilize this receptor in active, inactive, or ligand-specific conformations [88]. Similar to neutralizing antibodies, aptamers can block the interaction between ligand and receptor. Although not directed toward a GPCR, anti-PD-L1 aptamers block the PD-1/PD-L1 signaling axis, reducing tumor growth and improving immune surveillance [89]. An anti-CTLA-4 aptamer has also shown promise for delivering siRNA cargo. The lack of therapeutic efficacy of siRNA-mediated gene silencing is due in part to low siRNA internalization by tumor cells [90]. Conjugation of an anti-CTLA-4 aptamer to a STAT3 siRNA helped to overcome this limitation and achieved STAT3 gene silencing in both tumor-associated T cells and tumor cells [91,92]. GPCR-binding aptamers that disrupt ligand-receptor interactions and abrogate downstream GPCR signaling, or that improve delivery of either siRNAs or drug-loaded nanoparticles to tumors, could have application as new PDAC therapeutics [76].

\section{Conclusions}

Earlier detection and targeted therapies for pancreatic cancer will undoubtedly improve patient survival $[93,94]$. However, developing reagents capable of specifically targeting tumors for imaging and drug delivery remains a significant challenge. GPCRs represent a class of tumor cell surface proteins with well-characterized ligands, well-understood pathways for internalization and recycling, and well-documented signaling capabilities, including crosstalk with other oncogenic signaling pathways. Identifying and validating GPCR-specific imaging or therapeutic reagents could provide new tools to make clinically significant improvements in PDAC patient care and achieve the goal of improving survival rates for patients battling this disease.

Author Contributions: G.L.M. and J.F.H. contributed to writing, editing, and graphic design.

Funding: The Matters laboratory was supported by NIH R01 CA167535 and R21 CA170121. The content is solely the responsibility of the authors and does not necessarily represent the official views of the National Institutes of Health. Matters has also received funding from the Pennsylvania Department of Health's Tobacco CURE fund. The Department of Health specifically disclaims responsibility for any analysis, interpretations, or conclusions.

Acknowledgments: We thank Christopher McGovern for critical readings of the manuscript.

Conflicts of Interest: The authors declare no conflict of interest.

\section{References}

1. Liu, D.; Auguste, D.T. Cancer targeted therapeutics: From molecules to drug delivery vehicles. J. Control. Release 2015, 219, 632-643. [CrossRef] [PubMed] 
2. O'Connor, J.P.; Aboagye, E.O.; Adams, J.E.; Aerts, H.J.; Barrington, S.F.; Beer, A.J.; Boellaard, R.; Bohndiek, S.E.; Brady, M.; Brown, G.; et al. Imaging biomarker roadmap for cancer studies. Nat. Rev.. Clin. Oncol. 2017, 14, 169-186. [CrossRef] [PubMed]

3. Srinivasarao, M.; Galliford, C.V.; Low, P.S. Principles in the design of ligand-targeted cancer therapeutics and imaging agents. Nat. Rev. Drug Discov. 2015, 14, 203-219. [CrossRef] [PubMed]

4. Hussain, S.; Rodriguez-Fernandez, M.; Braun, G.B.; Doyle, F.J.; Ruoslahti, E. Quantity and accessibility for specific targeting of receptors in tumours. Sci. Rep. 2014, 4, 5232. [CrossRef] [PubMed]

5. Mosquera, C.; Maglic, D.; Zervos, E.E. Molecular targeted therapy for pancreatic adenocarcinoma: A review of completed and ongoing late phase clinical trials. Cancer Genet. 2016, 209, 567-581. [CrossRef] [PubMed]

6. Sriram, K.; Insel, P.A. G protein-coupled receptors as targets for approved drugs: How many targets and how many drugs? Mol. Pharmacol. 2018, 93, 251-258. [CrossRef] [PubMed]

7. Dorsam, R.T.; Gutkind, J.S. G-protein-coupled receptors and cancer. Nat. Rev. Cancer 2007, 7, 79-94. [CrossRef] [PubMed]

8. O'Hayre, M.; Degese, M.S.; Gutkind, J.S. Novel insights into g protein and g protein-coupled receptor signaling in cancer. Curr. Opin. Cell Biol. 2014, 27, 126-135. [CrossRef] [PubMed]

9. Kang, D.S.; Tian, X.; Benovic, J.L. Role of beta-arrestins and arrestin domain-containing proteins in g protein-coupled receptor trafficking. Curr. Opin. Cell Biol. 2014, 27, 63-71. [CrossRef] [PubMed]

10. Nieto Gutierrez, A.; McDonald, P.H. Gpcrs: Emerging anti-cancer drug targets. Cell. Signal. 2018, 41, 65-74. [CrossRef] [PubMed]

11. Sanderson, M.P.; Keller, S.; Alonso, A.; Riedle, S.; Dempsey, P.J.; Altevogt, P. Generation of novel, secreted epidermal growth factor receptor (EGFR/ERBB1) isoforms via metalloprotease-dependent ectodomain shedding and exosome secretion. J. Cell. Biochem. 2008, 103, 1783-1797. [CrossRef] [PubMed]

12. Miller, M.A.; Sullivan, R.J.; Lauffenburger, D.A. Molecular pathways: Receptor ectodomain shedding in treatment, resistance, and monitoring of cancer. Clin. Cancer Res. 2017, 23, 623-629. [CrossRef] [PubMed]

13. Heasley, L.E. Autocrine and paracrine signaling through neuropeptide receptors in human cancer. Oncogene 2001, 20, 1563-1569. [CrossRef] [PubMed]

14. O’Hayre, M.; Vazquez-Prado, J.; Kufareva, I.; Stawiski, E.W.; Handel, T.M.; Seshagiri, S.; Gutkind, J.S. The emerging mutational landscape of g proteins and g-protein-coupled receptors in cancer. Nat. Rev. Cancer 2013, 13, 412-424. [CrossRef] [PubMed]

15. Natarajan, K.; Berk, B.C. Crosstalk coregulation mechanisms of g protein-coupled receptors and receptor tyrosine kinases. Methods Mol. Biol. 2006, 332, 51-77. [PubMed]

16. Logsdon, C.D.; Lu, W. The significance of ras activity in pancreatic cancer initiation. Int. J. Biol. Sci. 2016, 12, 338-346. [CrossRef] [PubMed]

17. Bird, J.L.; Simpson, R.; Vllasaliu, D.; Goddard, A.D. Neurotensin receptor 1 facilitates intracellular and transepithelial delivery of macromolecules. Eur. J. Pharm. Biopharm. 2017, 119, 300-309. [CrossRef] [PubMed]

18. Accardo, A.; Aloj, L.; Aurilio, M.; Morelli, G.; Tesauro, D. Receptor binding peptides for target-selective delivery of nanoparticles encapsulated drugs. Int. J. Nanomed. 2014, 9, 1537-1557.

19. Smith, J.P.; Fonkoua, L.K.; Moody, T.W. The role of gastrin and cck receptors in pancreatic cancer and other malignancies. Int. J. Biol. Sci. 2016, 12, 283-291. [CrossRef] [PubMed]

20. Dockray, G.J.; Moore, A.; Varro, A.; Pritchard, D.M. Gastrin receptor pharmacology. Curr. Gastroenterol. Rep. 2012, 14, 453-459. [CrossRef] [PubMed]

21. Foucaud, M.; Archer-Lahlou, E.; Marco, E.; Tikhonova, I.G.; Maigret, B.; Escrieut, C.; Langer, I.; Fourmy, D. Insights into the binding and activation sites of the receptors for cholecystokinin and gastrin. Regul. Pept. 2008, 145, 17-23. [CrossRef] [PubMed]

22. Goetze, J.P.; Nielsen, F.C.; Burcharth, F.; Rehfeld, J.F. Closing the gastrin loop in pancreatic carcinoma: Coexpression of gastrin and its receptor in solid human pancreatic adenocarcinoma. Cancer 2000, 88, 2487-2494. [CrossRef]

23. Tohidkia, M.R.; Asadi, F.; Barar, J.; Omidi, Y. Selection of potential therapeutic human single-chain $\mathrm{fv}$ antibodies against cholecystokinin-b/gastrin receptor by phage display technology. BioDrugs Clin. Immunother. Biopharm. Gene Ther. 2013, 27, 55-67. [CrossRef] [PubMed]

24. Jo, M.; Jung, S.T. Engineering therapeutic antibodies targeting g-protein-coupled receptors. Exp. Mol. Med. 2016, 48, e207. [CrossRef] [PubMed] 
25. Laverman, P.; Roosenburg, S.; Gotthardt, M.; Park, J.; Oyen, W.J.; de Jong, M.; Hellmich, M.R.; Rutjes, F.P.; van Delft, F.L.; Boerman, O.C. Targeting of a CCK(2) receptor splice variant with (111)In-labelled cholecystokinin-8 (CCK8) and (111)In-labelled minigastrin. Eur. J. Nucl. Med. Mol. Imaging 2008, 35, 386-392. [CrossRef] [PubMed]

26. Sosabowski, J.K.; Matzow, T.; Foster, J.M.; Finucane, C.; Ellison, D.; Watson, S.A.; Mather, S.J. Targeting of cck-2 receptor-expressing tumors using a radiolabeled divalent gastrin peptide. J. Nucl. Med. 2009, 50, 2082-2089. [CrossRef] [PubMed]

27. Brom, M.; Joosten, L.; Laverman, P.; Oyen, W.J.; Behe, M.; Gotthardt, M.; Boerman, O.C. Preclinical evaluation of 68ga-dota-minigastrin for the detection of cholecystokinin-2/gastrin receptor-positive tumors. Mol. Imaging 2011, 10, 144-152. [CrossRef] [PubMed]

28. Behr, T.M.; Behe, M.; Angerstein, C.; Gratz, S.; Mach, R.; Hagemann, L.; Jenner, N.; Stiehler, M.; Frank-Raue, K.; Raue, F.; et al. Cholecystokinin-B/gastrin receptor binding peptides: Preclinical development and evaluation of their diagnostic and therapeutic potential. Clin. Cancer Res. 1999, 5, 3124s-3138s. [CrossRef] [PubMed]

29. Aloj, L.; Caraco, C.; Panico, M.; Zannetti, A.; Del Vecchio, S.; Tesauro, D.; De Luca, S.; Arra, C.; Pedone, C.; Morelli, G.; et al. In vitro and in vivo evaluation of 111In-DTPAGLU-G-CCK8 for cholecystokinin-B receptor imaging. J. Nucl. Med. 2004, 45, 485-494. [PubMed]

30. Nock, B.A.; Maina, T.; Behe, M.; Nikolopoulou, A.; Gotthardt, M.; Schmitt, J.S.; Behr, T.M.; Macke, H.R. CCK-2/gastrin receptor-targeted tumor imaging with (99m)Tc-labeled minigastrin analogs. J. Nucl. Med. 2005, 46, 1727-1736. [PubMed]

31. Kaloudi, A.; Nock, B.A.; Krenning, E.P.; Maina, T.; De Jong, M. Radiolabeled gastrin/cck analogs in tumor diagnosis: Towards higher stability and improved tumor targeting. Q. J. Nucl. Med. Mol. Imaging 2015, 59, 287-302. [PubMed]

32. Breeman, W.A.; Froberg, A.C.; de Blois, E.; van Gameren, A.; Melis, M.; de Jong, M.; Maina, T.; Nock, B.A.; Erion, J.L.; Macke, H.R.; et al. Optimised labeling, preclinical and initial clinical aspects of cck-2 receptor-targeting with 3 radiolabeled peptides. Nucl. Med. Biol. 2008, 35, 839-849. [CrossRef] [PubMed]

33. Kaloudi, A.; Nock, B.A.; Lymperis, E.; Krenning, E.P.; de Jong, M.; Maina, T. Improving the in vivo profile of minigastrin radiotracers: A comparative study involving the neutral endopeptidase inhibitor phosphoramidon. Cancer Biother. Radiopharm. 2016, 31, 20-28. [CrossRef] [PubMed]

34. Kaloudi, A.; Nock, B.A.; Lymperis, E.; Sallegger, W.; Krenning, E.P.; de Jong, M.; Maina, T. In vivo inhibition of neutral endopeptidase enhances the diagnostic potential of truncated gastrin (111)In-radioligands. Nucl. Med. Biol. 2015, 42, 824-832. [CrossRef] [PubMed]

35. Kaloudi, A.; Nock, B.A.; Lymperis, E.; Valkema, R.; Krenning, E.P.; de Jong, M.; Maina, T. Impact of clinically tested NEP / ACE inhibitors on tumor uptake of [(111)In-DOTA]MG11-first estimates for clinical translation. EJNMMI Res. 2016, 6, 15. [CrossRef] [PubMed]

36. Barth, B.M.; Sharma, R.; Altinoglu, E.I.; Morgan, T.T.; Shanmugavelandy, S.S.; Kaiser, J.M.; McGovern, C.O.; Matters, G.L.; Smith, J.P.; Kester, M.; et al. Bioconjugation of calcium phosphosilicate composite nanoparticles for selective targeting of huan breast and pancreatic cancers in vivo. ACS Nano 2010, 4, 1279-1287. [CrossRef] [PubMed]

37. Szepeshazi, K.; Schally, A.V.; Nagy, A.; Halmos, G. Inhibition of growth of experimental human and hamster pancreatic cancers in vivo by a targeted cytotoxic bombesin analog. Pancreas 2005, 31, 275-282. [CrossRef] [PubMed]

38. Sancho, V.; Di Florio, A.; Moody, T.W.; Jensen, R.T. Bombesin receptor-mediated imaging and cytotoxicity: Review and current status. Curr. Drug Deliv. 2011, 8, 79-134. [CrossRef] [PubMed]

39. Yu, Z.; Ananias, H.J.; Carlucci, G.; Hoving, H.D.; Helfrich, W.; Dierckx, R.A.; Wang, F.; de Jong, I.J.; Elsinga, P.H. An update of radiolabeled bombesin analogs for gastrin-releasing peptide receptor targeting. Curr. Pharm. Des. 2013, 19, 3329-3341. [CrossRef] [PubMed]

40. Safavy, A.; Raisch, K.P.; Matusiak, D.; Bhatnagar, S.; Helson, L. Single-drug multiligand conjugates: Synthesis and preliminary cytotoxicity evaluation of a paclitaxel-dipeptide "scorpion" molecule. Bioconjug. Chem. 2006, 17, 565-570. [CrossRef] [PubMed]

41. Nagy, A.; Armatis, P.; Cai, R.Z.; Szepeshazi, K.; Halmos, G.; Schally, A.V. Design, synthesis, and in vitro evaluation of cytotoxic analogs of bombesin-like peptides containing doxorubicin or its intensely potent derivative, 2-pyrrolinodoxorubicin. Proc. Natl. Acad. Sci. USA 1997, 94, 652-656. [CrossRef] [PubMed] 
42. Moody, T.W.; Sun, L.C.; Mantey, S.A.; Pradhan, T.; Mackey, L.V.; Gonzales, N.; Fuselier, J.A.; Coy, D.H.; Jensen, R.T. In vitro and in vivo antitumor effects of cytotoxic camptothecin-bombesin conjugates are mediated by specific interaction with cellular bombesin receptors. J. Pharmacol. Exp. Ther. 2006, 318, 1265-1272. [CrossRef] [PubMed]

43. Ramos-Alvarez, I.; Moreno, P.; Mantey, S.A.; Nakamura, T.; Nuche-Berenguer, B.; Moody, T.W.; Coy, D.H.; Jensen, R.T. Insights into bombesin receptors and ligands: Highlighting recent advances. Peptides 2015, 72, 128-144. [CrossRef] [PubMed]

44. Munoz, M.; Covenas, R. Involvement of substance $\mathrm{p}$ and the $\mathrm{nk}-1$ receptor in pancreatic cancer. World J. Gastroenterol. 2014, 20, 2321-2334. [CrossRef] [PubMed]

45. Li, X.; Ma, G.; Ma, Q.; Li, W.; Liu, J.; Han, L.; Duan, W.; Xu, Q.; Liu, H.; Wang, Z.; et al. Neurotransmitter substance p mediates pancreatic cancer perineural invasion via NK-1R in cancer cells. Mol. Cancer Res. 2013, 11, 294-302. [CrossRef] [PubMed]

46. Sinha, S.; Fu, Y.Y.; Grimont, A.; Ketcham, M.; Lafaro, K.; Saglimbeni, J.A.; Askan, G.; Bailey, J.M.; Melchor, J.P.; Zhong, Y.; et al. Panin neuroendocrine cells promote tumorigenesis via neuronal crosstalk. Cancer Res. 2017, 77, 1868-1879. [CrossRef] [PubMed]

47. Kanduluru, A.K.; Srinivasarao, M.; Low, P.S. Design, synthesis, and evaluation of a neurokinin-1 receptor-targeted near-IR dye for fluorescence-guided surgery of neuroendocrine cancers. Bioconjug. Chem. 2016, 27, 2157-2165. [CrossRef] [PubMed]

48. Low, P.S.; Singhal, S.; Srinivasarao, M. Fluorescence-guided surgery of cancer: Applications, tools and perspectives. Curr. Opin. Chem. Biol. 2018, 45, 64-72. [CrossRef] [PubMed]

49. Zhang, H.; Kanduluru, A.K.; Desai, P.; Ahad, A.; Carlin, S.; Tandon, N.; Weber, W.A.; Low, P.S. Synthesis and evaluation of a novel (64) Cu- and (67)Ga-labeled neurokinin 1 receptor antagonist for in vivo targeting of NK1R-positive tumor xenografts. Bioconjug. Chem. 2018, 29, 1319-1326. [CrossRef] [PubMed]

50. Kanduluru, A.K.; Low, P.S. Development of a ligand-targeted therapeutic agent for neurokinin-1 receptor expressing cancers. Mol. Pharm. 2017, 14, 3859-3865. [CrossRef] [PubMed]

51. Korner, M.; Waser, B.; Strobel, O.; Buchler, M.; Reubi, J.C. Neurotensin receptors in pancreatic ductal carcinomas. EJNMMI Res. 2015, 5, 17. [CrossRef] [PubMed]

52. Yin, X.; Wang, M.; Wang, H.; Deng, H.; He, T.; Tan, Y.; Zhu, Z.; Wu, Z.; Hu, S.; Li, Z. Evaluation of neurotensin receptor 1 as a potential imaging target in pancreatic ductal adenocarcinoma. Amino Acids 2017, 49, 1325-1335. [CrossRef] [PubMed]

53. Guha, S.; Lunn, J.A.; Santiskulvong, C.; Rozengurt, E. Neurotensin stimulates protein kinase c-dependent mitogenic signaling in human pancreatic carcinoma cell line PANC-1. Cancer Res. 2003, 63, 2379-2387. [PubMed]

54. Wang, J.G.; Li, N.N.; Li, H.N.; Cui, L.; Wang, P. Pancreatic cancer bears overexpression of neurotensin and neurotensin receptor subtype-1 and SR 48692 counteracts neurotensin induced cell proliferation in human pancreatic ductal carcinoma cell line PANC-1. Neuropeptides 2011, 45, 151-156. [CrossRef] [PubMed]

55. Maschauer, S.; Einsiedel, J.; Hubner, H.; Gmeiner, P.; Prante, O. (18)F- and (68)Ga-labeled neurotensin peptides for PET imaging of neurotensin receptor 1. J. Med. Chem. 2016, 59, 6480-6492. [CrossRef] [PubMed]

56. Maschauer, S.; Prante, O. Radiopharmaceuticals for imaging and endoradiotherapy of neurotensin receptor-positive tumors. J. Label. Compd. Radiopharm. 2018, 61, 309-325. [CrossRef] [PubMed]

57. Schulz, J.; Rohracker, M.; Stiebler, M.; Goldschmidt, J.; Grosser, O.S.; Osterkamp, F.; Pethe, A.; Reineke, U.; Smerling, C.; Amthauer, H. Comparative evaluation of the biodistribution profiles of a series of nonpeptidic neurotensin receptor- 1 antagonists reveals a promising candidate for theranostic applications. J. Nucl. Med. 2016, 57, 1120-1123. [CrossRef] [PubMed]

58. Falciani, C.; Brunetti, J.; Lelli, B.; Accardo, A.; Tesauro, D.; Morelli, G.; Bracci, L. Nanoparticles exposing neurotensin tumor-specific drivers. J. Pept. Sci. 2013, 19, 198-204. [CrossRef] [PubMed]

59. Hao, F.; Xu, Q.; Zhao, Y.; Stevens, J.V.; Young, S.H.; Sinnett-Smith, J.; Rozengurt, E. Insulin receptor and GPCR crosstalk stimulates YAP via PI3K and PKD in pancreatic cancer cells. Mol. Cancer Res. 2017, 15, 929-941. [CrossRef] [PubMed]

60. Rozengurt, E.; Sinnett-Smith, J.; Eibl, G. Yes-associated protein (YAP) in pancreatic cancer: At the epicenter of a targetable signaling network associated with patient survival. Signal Transduct. Targeted Ther. 2018, 3, 11. [CrossRef] [PubMed] 
61. Shahbaz, M.; Ruliang, F.; Xu, Z.; Benjia, L.; Cong, W.; Zhaobin, H.; Jun, N. Mrna expression of somatostatin receptor subtypes SSTR-2, SSTR-3, and SSTR-5 and its significance in pancreatic cancer. World J. Surg. Oncol. 2015, 13, 46. [CrossRef] [PubMed]

62. Chalabi-Dchar, M.; Cassant-Sourdy, S.; Duluc, C.; Fanjul, M.; Lulka, H.; Samain, R.; Roche, C.; Breibach, F.; Delisle, M.B.; Poupot, M.; et al. Loss of somatostatin receptor subtype 2 promotes growth of KRAS-induced pancreatic tumors in mice by activating PI3K signaling and overexpression of CXCL16. Gastroenterology 2015, 148, 1452-1465. [CrossRef] [PubMed]

63. De Jong, M.; Breeman, W.A.; Kwekkeboom, D.J.; Valkema, R.; Krenning, E.P. Tumor imaging and therapy using radiolabeled somatostatin analogues. Acc. Chem. Res. 2009, 42, 873-880. [CrossRef] [PubMed]

64. Wolin, E.M. The expanding role of somatostatin analogs in the management of neuroendocrine tumors. Gastrointest. Cancer Res. 2012, 5, 161-168. [PubMed]

65. Sun, L.C.; Coy, D.H. Somatostatin receptor-targeted anti-cancer therapy. Curr. Drug Deliv. 2011, 8, 2-10. [CrossRef] [PubMed]

66. Sun, L.C.; Mackey, L.V.; Luo, J.; Fuselier, J.A.; Coy, D.H. Targeted chemotherapy using a cytotoxic somatostatin conjugate to inhibit tumor growth and metastasis in nude mice. Clin. Med. Oncol. 2008, 2, 491-499. [CrossRef] [PubMed]

67. Ahmadi, Y.; Kostenich, G.; Oron-Herman, M.; Wadsak, W.; Mitterhauser, M.; Orenstein, A.; Mirzaei, S.; Knoll, P. In vivo magnetic resonance imaging of pancreatic tumors using iron oxide nanoworms targeted with PTR86 peptide. Colloids Surf. B Biointerfaces 2017, 158, 423-430. [CrossRef] [PubMed]

68. Ghosh, S.C.; Hernandez Vargas, S.; Rodriguez, M.; Kossatz, S.; Voss, J.; Carmon, K.S.; Reiner, T.; Schonbrunn, A.; Azhdarinia, A. Synthesis of a fluorescently labeled (68)Ga-DOTA-TOC analog for somatostatin receptor targeting. ACS Med. Chem. Lett. 2017, 8, 720-725. [CrossRef] [PubMed]

69. Jorand, R.; Biswas, S.; Wakefield, D.L.; Tobin, S.J.; Golfetto, O.; Hilton, K.; Ko, M.; Ramos, J.W.; Small, A.R.; $\mathrm{Chu}$, P.; et al. Molecular signatures of mu opioid receptor and somatostatin receptor 2 in pancreatic cancer. Mol. Biol. Cell 2016, 27, 3659-3672. [CrossRef] [PubMed]

70. Maddipati, R.; Stanger, B.Z. Pancreatic cancer metastases harbor evidence of polyclonality. Cancer Discov. 2015, 5, 1086-1097. [CrossRef] [PubMed]

71. Ehlerding, E.B.; Sun, L.; Lan, X.; Zeng, D.; Cai, W. Dual-targeted molecular imaging of cancer. J. Nucl. Med. 2018, 59, 390-395. [CrossRef] [PubMed]

72. Xu, L.; Josan, J.S.; Vagner, J.; Caplan, M.R.; Hruby, V.J.; Mash, E.A.; Lynch, R.M.; Morse, D.L.; Gillies, R.J. Heterobivalent ligands target cell-surface receptor combinations in vivo. Proc. Natl. Acad. Sci. USA 2012, 109, 21295-21300. [CrossRef] [PubMed]

73. Zhang, J.; Niu, G.; Lang, L.; Li, F.; Fan, X.; Yan, X.; Yao, S.; Yan, W.; Huo, L.; Chen, L.; et al. Clinical translation of a dual integrin alphavbeta3- and gastrin-releasing peptide receptor-targeting pet radiotracer, 68ga-BBN-RGD. J. Nucl. Med. 2017, 58, 228-234. [CrossRef] [PubMed]

74. Luo, H.; England, C.G.; Goel, S.; Graves, S.A.; Ai, F.; Liu, B.; Theuer, C.P.; Wong, H.C.; Nickles, R.J.; Cai, W. Immunopet and near-infrared fluorescence imaging of pancreatic cancer with a dual-labeled bispecific antibody fragment. Mol. Pharm. 2017, 14, 1646-1655. [CrossRef] [PubMed]

75. Luo, H.; England, C.G.; Shi, S.; Graves, S.A.; Hernandez, R.; Liu, B.; Theuer, C.P.; Wong, H.C.; Nickles, R.J.; Cai, W. Dual targeting of tissue factor and cd105 for preclinical pet imaging of pancreatic cancer. Clin. Cancer Res. 2016, 22, 3821-3830. [CrossRef] [PubMed]

76. Rothlisberger, P.; Gasse, C.; Hollenstein, M. Nucleic acid aptamers: Emerging applications in medical imaging, nanotechnology, neurosciences, and drug delivery. Int. J. Mol. Sci. 2017, 18, 2430. [CrossRef] [PubMed]

77. Tawiah, K.D.; Porciani, D.; Burke, D.H. Toward the selection of cell targeting aptamers with extended biological functionalities to facilitate endosomal escape of cargoes. Biomedicines 2017, 5, 51. [CrossRef] [PubMed]

78. Xiang, D.; Zheng, C.; Zhou, S.F.; Qiao, S.; Tran, P.H.; Pu, C.; Li, Y.; Kong, L.; Kouzani, A.Z.; Lin, J.; et al. Superior performance of aptamer in tumor penetration over antibody: Implication of aptamer-based theranostics in solid tumors. Theranostics 2015, 5, 1083-1097. [CrossRef] [PubMed]

79. Yoon, S.; Rossi, J.J. Emerging cancer-specific therapeutic aptamers. Curr. Opin. Oncol. 2017, $29,366-374$. [CrossRef] [PubMed] 
80. Hori, S.I.; Herrera, A.; Rossi, J.J.; Zhou, J. Current advances in aptamers for cancer diagnosis and therapy. Cancers 2018, 10, 9. [CrossRef] [PubMed]

81. Li, X.; Zhao, Q.; Qiu, L. Smart ligand: Aptamer-mediated targeted delivery of chemotherapeutic drugs and sirna for cancer therapy. J. Control. Release 2013, 171, 152-162. [CrossRef] [PubMed]

82. Catuogno, S.; Esposito, C.L.; de Franciscis, V. Aptamer-mediated targeted delivery of therapeutics: An update. Pharmaceuticals 2016, 9, 69. [CrossRef] [PubMed]

83. Alshaer, W.; Ababneh, N.; Hatmal, M.; Izmirli, H.; Choukeife, M.; Shraim, A.; Sharar, N.; Abu-Shiekah, A.; Odeh, F.; Al Bawab, A.; et al. Selection and targeting of epcam protein by ssdna aptamer. PLoS ONE 2017, 12, e0189558. [CrossRef] [PubMed]

84. Melancon, M.P.; Zhou, M.; Zhang, R.; Xiong, C.; Allen, P.; Wen, X.; Huang, Q.; Wallace, M.; Myers, J.N.; Stafford, R.J.; et al. Selective uptake and imaging of aptamer- and antibody-conjugated hollow nanospheres targeted to epidermal growth factor receptors overexpressed in head and neck cancer. ACS Nano 2014, 8 , 4530-4538. [CrossRef] [PubMed]

85. Pei, X.; Zhang, J.; Liu, J. Clinical applications of nucleic acid aptamers in cancer. Mol. Clin. Oncol. 2014, 2, 341-348. [CrossRef] [PubMed]

86. Clawson, G.A.; Abraham, T.; Pan, W.; Tang, X.; Linton, S.S.; McGovern, C.O.; Loc, W.S.; Smith, J.P.; Butler, P.J.; Kester, M.; et al. A cholecystokinin b receptor-specific DNA aptamer for targeting pancreatic ductal adenocarcinoma. Nucleic Acid Ther. 2016, 27, 23-35. [CrossRef] [PubMed]

87. Daniels, D.A.; Sohal, A.K.; Rees, S.; Grisshammer, R. Generation of rna aptamers to the g-protein-coupled receptor for neurotensin, NTS-1. Anal. Biochem. 2002, 305, 214-226. [CrossRef] [PubMed]

88. Kahsai, A.W.; Wisler, J.W.; Lee, J.; Ahn, S.; Cahill Iii, T.J.; Dennison, S.M.; Staus, D.P.; Thomsen, A.R.; Anasti, K.M.; Pani, B.; et al. Conformationally selective rna aptamers allosterically modulate the beta2-adrenoceptor. Nat. Chem. Biol. 2016, 12, 709-716. [CrossRef] [PubMed]

89. Lai, W.Y.; Huang, B.T.; Wang, J.W.; Lin, P.Y.; Yang, P.C. A novel pd-11-targeting antagonistic DNA aptamer with antitumor effects. Mol. Ther. Nucleic Acids 2016, 5, e397. [CrossRef] [PubMed]

90. Shi, K.; Zhao, Y.; Miao, L.; Satterlee, A.; Haynes, M.; Luo, C.; Musetti, S.; Huang, L. Dual functional lipomet mediates envelope-type nanoparticles to combinational oncogene silencing and tumor growth inhibition. Mol. Ther. J. Am. Soc. Gene Ther. 2017, 25, 1567-1579. [CrossRef] [PubMed]

91. Herrmann, A.; Priceman, S.J.; Swiderski, P.; Kujawski, M.; Xin, H.; Cherryholmes, G.A.; Zhang, W.; Zhang, C.; Lahtz, C.; Kowolik, C.; et al. Ctla4 aptamer delivers stat3 sirna to tumor-associated and malignant T cells. J. Clin. Investig. 2014, 124, 2977-2987. [CrossRef] [PubMed]

92. Huang, B.T.; Lai, W.Y.; Chang, Y.C.; Wang, J.W.; Yeh, S.D.; Lin, E.P.; Yang, P.C. A ctla-4 antagonizing DNA aptamer with antitumor effect. Mol. Ther. Nucleic Acids 2017, 8, 520-528. [CrossRef] [PubMed]

93. Seufferlein, T.; Mayerle, J. Pancreatic cancer in 2015: Precision medicine in pancreatic cancer-Fact or fiction? Nat. Rev. Gastroenterol. Hepatol. 2016, 13, 74-75. [CrossRef] [PubMed]

94. Kenner, B.J.; Chari, S.T.; Maitra, A.; Srivastava, S.; Cleeter, D.F.; Go, V.L.; Rothschild, L.J.; Goldberg, A.E. Early detection of pancreatic cancer-a defined future using lessons from other cancers: A white paper. Pancreas 2016, 45, 1073-1079. [CrossRef] [PubMed]

(c) 2018 by the authors. Licensee MDPI, Basel, Switzerland. This article is an open access article distributed under the terms and conditions of the Creative Commons Attribution (CC BY) license (http://creativecommons.org/licenses/by/4.0/). 